\title{
Phytochemical Screening and Antioxidant Activity of Date(Phoenix Dactylifera) Seed Extracts
}

\author{
Siti Warnasih, Diana Widiastuti, Uswatun Hasanah, Laksmi Ambarsari, \\ Purwantiningsih Sugita
}

\begin{abstract}
Dates consisting of $90 \%$ flesh have been known to have various benefits, but the remaining $10 \%$ of them in the form of seeds has not been utilized optimally. The date palm contains a fairly high polyphenol compound, which can act as an antioxidant. This study aims to determine the antioxidant activity of methanol extract and fractionation of the extract of dates using the in vitro method of DPPH (1,1-diphenyl-2-picrilhidrazil). The date seeds are made into simplicia, macerated with methanol, and then the extracted methanol is gradually fractionated by $n$-hexane, ethyl acetate, n-butanol, and water. Each fraction and extract is phytochemically screened using the standard methods and its antioxidant activity is determined by DPPH method. Methanol extract, ethyl acetate, n-butanol, and water fractions contain tannins, flavonoids, alkaloids, and saponin, while the n-hexane fraction not contain phytochemical compound based on the phytochemical screening. The ethyl acetate fraction has the strongest antioxidant activity with the lowest $I_{50}$ value, that is equal to $3.72 \pm 0.44 \mu \mathrm{g} / \mathrm{mL}$, followed by methanol extract of 4.71 $\pm 0.64 \mu \mathrm{g} / \mathrm{mL}, \mathrm{n}$-butanol fraction of $6.62 \pm 0.08 \mu \mathrm{g} / \mathrm{mL}$, water fraction of $53.00 \pm 18.96 \mu \mathrm{g} / \mathrm{mL}$, and $n$-hexane fraction of $250.19 \pm 9.69 \mu \mathrm{g} / \mathrm{mL}$, while the $I C_{50}$ value of vitamin $C$ as the positive control is $4.29 \pm 0.74 \mu \mathrm{g} / \mathrm{mL}$. Therefore, date seeds can be a source of natural antioxidants.
\end{abstract}

Index Terms: Antioxidants, Date seeds, DPPH, Phytochemicals.

\section{INTRODUCTION}

Free radicals are unstable and reactive substances because they have one or more unpaired electrons, so to achieve free radical stability they can easily react with other molecules, such as carbohydrates, fats, proteins, and DNA. Therefore, the more one's body is exposed to free radicals the more easily he is attacked by diseases such as cancer, AIDS, central nervous system damage, etc. [1]. Free radicals can be counteracted by consumption of synthetic or natural antioxidants. However, synthetic antioxidants such as

Revised Manuscript Received on April 25, 2019.

Siti Warnasih, Department of Chemistry, Pakuan University, Bogor, Indonesia.

Diana Widiastuti, Department of Chemistry, Pakuan University, Bogor, Indonesia.

Uswatun Hasanah, Department of Chemistry, Pakuan University, Bogor, Indonesia.

Laksmi Ambarsari, Department of Biochemistry, Bogor Agricultural Institute, Bogor, Indonesia.

Purwantinigsih Sugita, Department of Chemistry, Bogor Agricultural Institute, Bogor, Indonesia. butylhydroxyanisol (BHA) and butylhydroxy toluene (BHT) have negative effects on health, so there have been more researches for natural antioxidant sources.

Dates (Phoenix dactylifera) are an important source of food in the countries of the Middle East and North Africa. Dates contain high carbohydrates, about 77.34-84.45\%, depending on the varieties [2], and some important minerals such as iron, potassium, calcium, magnesium, manganese, sodium, copper, and zinc [3]. Dates are rich in antioxidants that can help in lowering the risk of cancer and boosting the immune system [4].

Dates consist of about $90 \%$ flesh and $10 \%$ seed that have not been utilized optimally, only used as animal feed ingredients [5]. Fresh date seeds contain of 3.1-7.1\% water, 2.3-6.4\% protein, $5.0-13.2 \%$ fat, $0.9-1.8 \%$ ash, $22.5-80.2 \%$ fiber and phenolic about 3102-4430 mg GAE/100 g [2], and also flavonoids about 1224-1844 mg RE/100 g [6]. Flavonoid compounds have been proven to have many benefits, namely to be antioxidants, anti-carcinogenic, anti-microbial, anti-mutagenic, anti-inflammatory, and reduce the risk of cardiovascular diseases [5].

The objective of this study is to determine the antioxidant activity of crude extract of methanol and the fractionation of date seeds with n-hexane, ethyl acetate, n-butanol, and water solvents.

\section{MATERIALS AND METHODS}

\section{A. Materials}

Date seeds of Shiva varieties (Egypt) are obtained from a date palm juice factory, CV. Amal Mulia Sejahtera, Bogor, West Java, Indonesia.

\section{B. Preparation of samples}

Date seeds are cleaned, washed, and dried in the oven at 50 ${ }^{0} \mathrm{C}$ overnight, then crushed into 40 mesh powder using a mill machine. Then it put in polyethylene plastic, and stored at 4 ${ }^{\circ} \mathrm{C}$ until analyzed.

\section{Determination of water content}

The determination of water content uses the Gravimetric method [7] and the analysis is repeated 3 times. 


\section{Extraction-fractionation}

$1 \mathrm{Kg}$ of date seed powder is macerated with methanol (1:2) at room temperature for $3 \times 24$ hours. The filtrate is filtered and concentrated with a vacuum evaporator at $40{ }^{\circ} \mathrm{C}$. The crude extract of methanol is then fractionated by multistage method of liquid-liquid partition,

10 gram of crude extract methanol is dissolved with $50 \mathrm{~mL}$ water, and $50 \mathrm{~mL}$-hexane is added, then extracted with a separating funnel to form two fractions, the lower fraction as a water fraction and the upper fraction as an $n$-hexane fraction, and the n-hexane fraction is separated and accommodated in vial I. The water fraction is added with 50 $\mathrm{mL}$ ethyl acetate, and then extracted with a separating funnel to form two fractions, the lower fraction as a water fraction and the upper fraction as an ethyl acetate fraction; the ethyl acetate fraction is separated and accommodated in vial II. The water fraction is added with $50 \mathrm{~mL}$ of $\mathrm{n}$-butanol, and then extracted with a separating funnel to form two fractions, the lower fraction as a water fraction and the upper fraction as an n-butanolfraction; the n-butanol fraction is separated and accommodated in vial III, while the water fraction is accommodated in vial IV. All fractions are concentrated with a vacuum evaporator at $40{ }^{\circ} \mathrm{C}$. The rendement of each fraction obtained is then calculated.

\section{E. Phytochemical qualitative test}

Methanol extract, n-hexane, ethyl acetate, n-butanol, and water fractions are tested for their phytochemical contents such as flavonoids, tannins, alkaloids, steroids, and terpenoids [8].

\section{F. Determination of antioxidant activity}

The determination of antioxidant activity applies the DPPH method (1,1-diphenyl-2-picrylhydrazyl) with UV-Vis spectrophotometry. The principle of this method is to measure DPPH radical capture by a compound having antioxidant activity using UV-Vis spectrophotometry so that it will show the value of free radical damping activity stated with $\mathrm{IC}_{50}$ (Inhibitory Concentration) value. Lower $\mathrm{IC}_{50}$ values will show better antioxidant activity. Vitamin $\mathrm{C}$ is used as the positive control standards.

\section{RESULT AND DISCUSSION}

The date seeds used in this study are made into dry simplicia and the water content is determined. The water content obtained is $9.10 \pm 0.47 \%$. The value of the water content is in accordance with the requirements of dry simplicia that is less than $10 \%$ [9]. Water content of less than $10 \%$ will make simplicia more resistant to contamination of microorganisms so that it can be stored for long periods of time.

The crude extract of methanol is 157 grams of $1 \mathrm{Kg}$ of macerated simplicia (15.7\%), the extract obtained is in the form of a brown sticky paste. Then, 6.1632 grams of methanol extract is partitioned with n-hexane, ethyl acetate, n-butanol, and water and results in 0.0313 grams of oily yellow n-hexane extract $(0.51 \%), 0.1978$ gram of brown paste ethyl acetate extract (3.21\%), 3.2124 gram of brown paste n-butanol extract (52.12\%), and 2.7217 gram of brown paste water extract $(44.16 \%)$ respectively.

\section{A. Phytochemical Qualitative Test}

Qualitative phytochemical screening of methanol extract and n-hexane, atil acetate, n-butanol, and date seed water fractions are done to determine the presence of secondary metabolites such as alkaloids, flavonoids, tannins, steroids, and terpenoids that act as antioxidants. The results of phytochemical screening show that methanol extract, ethyl acetate, n-butanol, and water fractions contain tannins, flavonoids, alkaloids, and saponin, while the n-hexane fraction not contain phytochemical compound, as shown in Table 1. These results correspond to the previous research that date seed extracts contain secondary metabolite compounds such as alkaloids, flavonoids, terpenoids, saponins, and tannins [10].

Table 1. Qualitative test results of phytochemical extract of date seeds

\begin{tabular}{|c|c|c|c|c|c|}
\hline \multirow{2}{*}{ Parameters } & \multicolumn{5}{|c|}{ Samples } \\
\cline { 2 - 6 } & $\begin{array}{c}\text { Methanol } \\
\text { extract }\end{array}$ & $\begin{array}{c}\text { n-hexanol } \\
\text { fraction }\end{array}$ & $\begin{array}{c}\text { Ethyl acetate } \\
\text { fraction }\end{array}$ & $\begin{array}{c}\text { n-butanol } \\
\text { fraction }\end{array}$ & $\begin{array}{c}\text { Water } \\
\text { fraction }\end{array}$ \\
\hline Alkaloids & + & - & + & + & + \\
\hline Flavonoids & + & - & + & + & + \\
\hline Tannins & + & - & + & + & + \\
\hline Saponins & + & - & + & + & + \\
\hline $\begin{array}{c}\text { Steroids and } \\
\text { Terpenoids }\end{array}$ & - & - & - & - & - \\
\hline
\end{tabular}

Alkaloids are one of the most important bioactive components in herbal plants, which can potentially be therapeutic agents. Flavonoids have potential as antibacterial, anti-inflammatory, and anti-thrombotic agents, while tannins and terpenoids can act as antioxidants. Saponin is an anti-inflammatory compound derived from plants [10].

\section{B. Antioxidant activity}

The antioxidant activity of the crude extract of methanol and its partition fraction is presented in Table 2. Antioxidant activity is expressed as $\mathrm{IC}_{50}$ value. $\mathrm{IC}_{50}$ is the concentration of sample required to inhibit DPPH free radicals by $50 \%$, the lower $\mathrm{IC}_{50}$ values the better antioxidant activity. The $\mathrm{IC}_{50}$ values for the crude extract of methanol, n-hexane, ethyl acetate, n-butanol, and water fractions are $4.71 \pm 0.64$ $\mu \mathrm{g} / \mathrm{mL}, 250.19 \pm 9.69 \mu \mathrm{g} / \mathrm{mL}, 3.72 \pm 0.44 \mu \mathrm{g} / \mathrm{mL}, 6.62 \pm$ $0.08 \mu \mathrm{g} / \mathrm{mL}$, and $53.00 \pm 18.96 \mu \mathrm{g} / \mathrm{mL}$ respectively, whereas the $\mathrm{IC}_{50}$ value for vitamin $\mathrm{C}$ as the positive control is $4.29 \pm$ $0.74 \mu \mathrm{g} / \mathrm{mL}$.

Based on these results, the crude methanol extract, ethyl acetate and n-butanol fractions are categorized as very strong as vitamin $\mathrm{C}$, water fraction is strong, and the $\mathrm{n}$-hexane fraction is very weak. This is consistent with the classification made by Molyneux [11], which is presented in Table 3. It is also consistent with the processing data results of the analysis method of variance (ANOVA) using SPSS where the methanol extract, ethyl acetate and n-butanol fractions, and vitamin $\mathrm{C}$ are not significantly different ( $\mathrm{p}>$ $0.05)$, while water and $n$-hexane 
fractions are significantly different $(\mathrm{p}<0.05)$, and the Duncan test shows that the $\mathrm{IC}_{50}$ values of methanol extract, ethyl acetate and n-butanol frac-

tions and vitamin $\mathrm{C}$ belong to a group of very strong antioxidants, while the water fraction is strong and the $\mathrm{n}$-hexane fraction is very weak.

Table 2. Antioxidant activity of date seed extracts

\begin{tabular}{|c|c|}
\hline Samples & $\mathrm{IC}_{50}(\mu \mathrm{g} / \mathrm{mL})$ \\
\hline Methanol extract & $4.71^{\mathrm{a}} \pm 0.64$ \\
\hline n-hexane fraction & $250.19^{\mathrm{c}} \pm 9.69$ \\
\hline Ethyl acetate fraction & $3.72^{\mathrm{a}} \pm 0.44$ \\
\hline n-butanol fraction & $6.62^{\mathrm{a}} \pm 0.08$ \\
\hline Water fraction & $53.00^{\mathrm{b}} \pm 18.96$ \\
\hline Vitamin C & $4.29^{\mathrm{a}} \pm 0.74$ \\
\hline
\end{tabular}

Values followed by different letters indicate real different treatments in the Duncan Test $(\alpha=0.05)$

The ethyl acetate fraction has the lowest $\mathrm{IC}_{50}$ value compared to the others, even compared with vitamin $\mathrm{C}$, while the n-hexane fraction has the highest $\mathrm{IC}_{50}$ value. This is consistent with the previous research, DegletNour varieties extracted with ethyl acetate has a $\mathrm{IC}_{50}$ value of $29 \mu \mathrm{g} / \mathrm{mL}$ or categorized as very active [3], while the $\mathrm{IC}_{50}$ value of methanol:water (4: 1) extract of Boufgous, Bousthammi, and Majhoul varieties are 166,112 , and $133 \mu \mathrm{g} / \mathrm{mL}$ respectively [6]. The antioxidant activity of plant extracts is determined by the presence of phenolic, tannin, and flavonoid compounds [3], and several previous studies have shown that there is a positive relationship between the total of phenol and the activity of antioxidants $[6,12,13]$.

Table 3. Classification of antioxidants [11]

\begin{tabular}{|c|c|}
\hline $\mathrm{IC}_{50}$ Concentration & Classification \\
\hline $\mathrm{IC}_{50} \leq 50 \mu \mathrm{g} / \mathrm{mL}$ & Very Stong \\
\hline $50 \mu \mathrm{g} / \mathrm{mL}<\mathrm{IC}_{50} \leq 100 \mu \mathrm{g} / \mathrm{mL}$ & Strong \\
\hline $100 \mu \mathrm{g} / \mathrm{mL}<\mathrm{IC}_{50} \leq 150 \mu \mathrm{g} / \mathrm{mL}$ & Medium \\
\hline $150 \mu \mathrm{g} / \mathrm{mL}<\mathrm{IC}_{50} \leq 200 \mu \mathrm{g} / \mathrm{mL}$ & Weak \\
\hline $\mathrm{IC}_{50}>200 \mu \mathrm{g} / \mathrm{mL}$ & Very Weak \\
\hline
\end{tabular}

\section{CONCLUSION}

In this study, ethyl acetate fraction has the highest antioxidant activity compared to that of methanol extract, $\mathrm{n}$-butanol, water, and n-hexane fractions. However, the methanol extract and the n-butanol fraction belong to very strong antioxidants just like the ethyl acetate fraction. Therefore, date seed can be a source of natural antioxidants such as vitamin C. Further research still needs to be done to determine the total phenolic and flavonoids contents that act as antioxidants.

\section{ACKNOWLEDGMENT}

I would like to especially thank to the Ministry of Research, Technology and Higher Education of the Republic of Indonesia for the financing of this research through the Inter-University Cooperation Research Grant in 2018.

\section{REFERENCES}

1. F. Pourmorad, S. J Hosseinimehr, N. Shahabimajd, “Antioxidant activity, phenol and flavonoid contents of some selected Iranian medicinal plants." African Journal of Biotechnology, vol. 5, no. 11, pp. 1142-1145, 2006.

2. M. Al-Farsi, C. Alasalvar, M. Al-Abid, K. Al-Shoaily, M. Al-Amry and F. Al-Rawahy, "Compositional and functional characteristics of dates, syrups, and their by-products." Food Chemistry, vol. 104, no. 3, pp. 943-947, 2007.

3. N. Chaira, A. Ferchichi, A. Mrabet and M. Sghairoun, "Chemical composition of the flesh and the pit of date palm fruit and radical scavenging activity of their extracts." Pakistan Journal of Biological Sciences,vol. 10, no. 13, pp. 2202-2207, 2007.

4. B. R. Yasin, H. A. N. El-Fawal and S. A. Mousa, "Date (Phoenix dactylifera) polyphenolics and other bioactive compounds: A traditional islamic remedy's potential in prevention of celldamage, cancer therapeutics and beyond." International Journal of Molecular Sciences,vol. 16, no. 12, pp. 30075-30090, 2015.

5. M. A. Al-Farsi and C. Y. Lee, "Optimization of phenolics and dietary fibre extraction from date seeds." Food Chemistry, vol. 108, no. 3, pp. 977-985, 2008

6. E. Bouhlali, T. Dine, C. Alem, J. Ennassir, M. Benlyas, A. N. Mbark and Y. F. Zegzouti, "Phytochemical compositions and antioxidant capacity of three date (Phoenix dactylifera L.) seeds varieties grown in the South East Morocco." Journal of the Saudi Society of Agricultural Sciences, vol. 16, no. 4, pp. 350-357, 2015.

7. W. Horwitz. Official methods of analysis. Washington: Association of Official Analytical Chemists, 1975.

8. J. B. Harborne, Phytochemical Methods. London: Chapman and Hall Ltd, 1987.

9. Departemen Kesehatan Republik Indonesia, Parameter Standar Umum Ekstrak Tumbuhan Obat. Jakarta: Direktorat Jenderal Pengawasan Obat dan Makanan, 2000.

10.A. M. Adeosun, S. O. Oni, O. M. Ighodaro, O. H. Durosinlorun and O. M. Oyedele, "Phytochemical, minerals and free radical scavenging profiles of Phoenix dactilyfera L. seed extract." Journal of Taibah University Medical Sciences, vol. 11, no. 1, pp. 1-6, 2016.

11.P. Molyneux, "The Use of the stable free radical Diphenylpicryl-hydrazyl (DPPH) for estimating antioxidant activity." Songklanakarin Journal of Science and Technology, vol. 26, no. 2, pp. 211-219, 2004.

12.M. R. S. Ardekani, M. Khanavi, M. Hajimahmoodi, M. Jahangiri, A. Hadjiakhoondi, "Comparison of antioxidant activity and total phenol contents of some date seed varieties from Iran." Iranian Journal of Pharmaceutical Research, vol. 9, no. 2, pp. 141-146, 2010.

13.R. Messaoudi, S. Abbeddou, A. Mansouri, A. C. Calokerinos, P. Kefalas, "Phenolic profile and antioxidant activity of date-pits of seven algerian date palm fruit varieties." International Journal of Food Properties, vol. 16, no. 5, 1037-1047, 2013. 